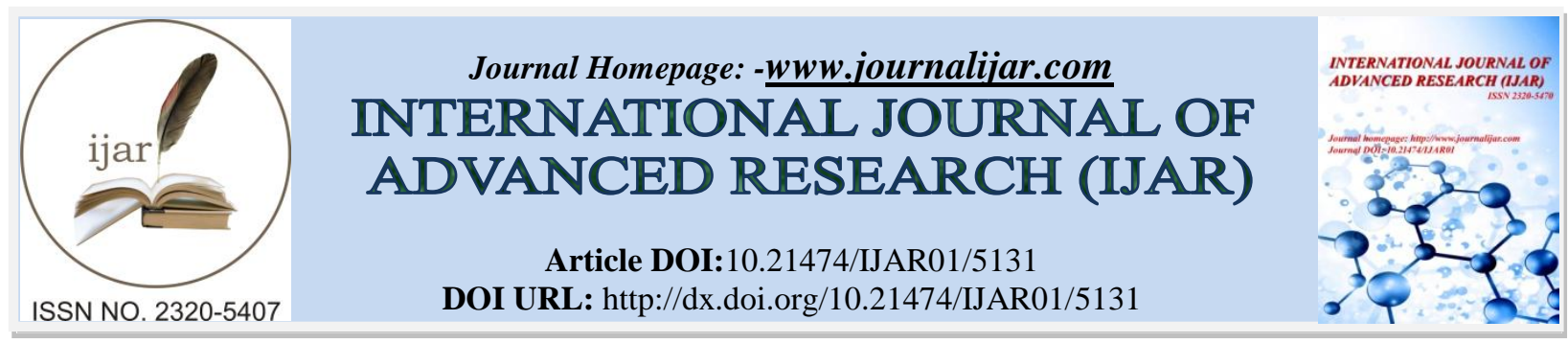

RESEARCH ARTICLE

\title{
PERCEPTION OF D.EL.ED. STUDENT-TEACHERS: A STUDY ON SOME ASPECTS OF EDUCATIONAL PERSPECTIVE.
}

\begin{abstract}
Akanksha Sharma
Sociology department Banasthali University

\section{Manuscript Info}

Manuscript History

Received: 10 June 2017

Final Accepted: 12 July 2017

Published: August 2017

Abstract

Teachers are the foundation stone of education system. Teacher facilitates and enables learning processes in students. And in order to make teachers competent government of India provides pre-service trainings to the student-teachers. Pre-service trainings consist of studies of theory and practice of teaching where practice teaching is a very crucial ingredient of the teaching. In general, the course has elements of psychology, educational philosophy and sociology of education and instructions about teaching of certain subjects. Also included are principles such as aims of education, curriculum, nature and characteristics of child development, method of teaching and learning and introduction to resources that a teacher must draw on. This study tries to investigate understanding of student-teachers on various aspects of Educational perspective like understanding of children, aims of education, learning environment, effective pedagogical techniques, teaching-learning processes, educational resources that enable teachers for effective classroom transaction etc. This study covers $44 \mathrm{D}$ El. Ed. Students from 2 DIETs mainly Dehradun and Roorkee. From the analysis of the data, it can be inferred that the perception of the studentteachers is aligned with the literature of National Curriculum Framework, 2005. Their perception is so aligned that there is no significant gap in the understanding of experienced and nonexperienced student-teachers, which highlights high transactional value of D. El Ed curriculum. Also, contrary to the myth that teacher opts for teaching as a profession because they are helpless and are left with no choice. The findings suggest that time is changing and today studentteachers aspire to become teachers because of their interest. The efforts need to be made to ensure that the student-teachers are allowed full autonomy to execute their understanding at school level.
\end{abstract}

Copy Right, IJAR, 2017,. All rights reserved.

\section{Context of Pre-service Education:-}

The teacher has always been considered in the core of education system as he/ she plays a pivotal role for the life of his/ her students. The trainings before and during service provides the platform in becoming an efficient professional teacher. The pre service teacher education transforms a person into a professional teacher practitioner. In India, the teacher education programs exist for over a century. In 1850s, teacher training existed as an undifferentiated course of study meant for school teachers. Later, on the recommendations of the Indian Education Commission (1884), the 
teacher training programs were made more differentiated and for graduates the course was designed to be of shorter duration ${ }^{1}$. After going through a number of changes from time to time today pre service education has become a necessity. The Yashpal Committee Report (1993) on learning without burden noted that inadequate programs of teacher preparation lead to unsatisfactory quality of learning in schools. Therefore the content of the programs have been reconstructed to increase its relevance to the changing needs of the school education.

The D. El. Ed curriculum aims at preparing teachers with a clear vision who can work according to the guidelines of National Curriculum Framework - 2005 and Right to Education Act - 2009. This is so because a teacher is expected to work according to the detailed framework of school education system. And to work according to National Curriculum Framework understanding child psychology and to be equipped with teaching material is not enough, it is also important to understand the parents, students and community which will lead to stability and increase in attendance and enrollment of the student.

There are various teaching contexts like - child study, contemporary study, educational study etc. that give opportunity for knowledge creation. This also aims at making the teachers competent who can also indulge in selfevaluation. According to NCF 2005, there are various demands and expectations from the teacher which should be addressed both by initial and continuing teacher education. Competent teachers hold utmost importance to the nations' school system and teacher competence, sensitivity and teacher motivation determine the quality and extent of learner achievement.

India has made considerable progress in school education since independence in terms of overall literacy, infrastructure and universal access and enrollment in schools. Two major developments have taken place in the recent years - the political recognition of Universalization of Elementary Education (UEE) as a legitimate demand and stat commitment towards UEE in the form of Right of children to free and compulsory education act - 2009, which has led to increase in demand for qualified elementary school teachers. In the coming years, our country has to meet the need of supplying well qualified and professionally trained teachers in large number.

Our perspective informs and determines the way we understand the world, ourselves, our behavior and actions and finally the life we live and foster. The issue of perspective becomes all more important for those working in education as the whole endeavor of education is for better more fulfilling lives for one and all. Perspective of teachers is formed by in-service and pre-service trainings. During pre-service trainings their perspective are enhanced by the curriculum of courses like B. Ed, D. EL ED etc. The D. El Ed. Curriculum includes various pre requisites, some of them are-

$>$ Childhood and Development of students ; Perspective in development, Childhood, Context of socialization : Relationship with teacher

$>$ Contemporary Indian society; Differential school system, Equality and Justice, Policies acts and provisions related to education and children with special references, Debates on globalization, Bodies of knowledge, Knowledge and power

$>$ Towards Understanding the self: Exploring the aim of life, Discovering one's true potential, Developing sensitivity, Facilitating personal growth

$>$ Cognitive, learning and socio - cultural context; Language and communication, Play, functions, group dynamics

> Teacher Identity and School culture; Creating a positive classroom culture, Developing research skills, Developing a vision of education

$>$ School culture, leadership and change ; School effectiveness and school standards, Change facilitation in education, Team leadership, Change management, Structure and processes of the Indian education system.

\section{Objectives:-}

This study tries to investigate understanding of student-teachers on various aspects of Educational perspective like understanding of children, aims of education, learning environment, effective pedagogical techniques, teachinglearning processes, educational resources that enable teachers for effective classroom transaction etc.

\footnotetext{
${ }^{1}$ Position Paper on Aims of Education (2006), Nation Council of Educational Research and Planning, India,P.2.
} 


\section{Coverage and Study Tool:-}

In Uttarakhand there are 13 DIET institutions. All 13 DIETs offer D. El Ed courses. Our study covers D. El Ed. Students from 2 DIETs mainly Dehradun and Roorkee. For this study, we made a semi structured interview schedule comprising of open ended questions and multiple responsive questions. This schedule was administered on 12 D. El Ed students enrolled in DIET Dehradun for the purpose of piloting. The inputs received during piloting of the tool were incorporated and the language of the schedule was also changed from English to Hindi to make it more respondent friendly. These schedules were finally administered on 44 students, 11 students from DIET Dehradun and 33 students from DIET Roorkee. While collecting final data from the students it was decided not to interview students who have participated in piloting of the study. Brief profile of respondents is presented ahead-

\begin{tabular}{|lc|} 
Total student Teachers (Male - 26, Female 17) & $: 44$ \\
Student-Teachers with age group 20 - 25 years & $: 26$ \\
Student-Teachers with age group 26 - 30 years & $: 13$ \\
Student-Teachers with age group 30 years and above & $: 5$ \\
Post Graduate Student-Teachers & $: 32$ \\
Student-Teachers with B. Ed degree & $: 24$ \\
Student-Teachers with professional skills other than B.ED & $: 13$ \\
Student-teachers with teaching experience (2 months - 16 years) & \\
\hline
\end{tabular}

There were 20 questions in which 6 were multiple responsive questions and 14 were open ended questions in the schedule. Questions covered areas likeAims of Education, coverage and study tool, why teaching as a profession, Issues that need to be addressed, Learning environment, Beliefs of teacher, Understanding children and resources support.

\section{Analysis and Interpretation:-}

The definiteness of aims and objectives of education are crucial. Education without aims has no aims. School education is a deliberate and more or less external intervention in the life of a child. Although much learning and teaching takes place at home, in the neighborhood community etc., the school introduces the child to formal system of education. So, the school must facilitate the creation of vital links between children's experience at home and in the community and what the school offers them. ${ }^{2}$

Education must be continuous process of self-discovery, of learning the truth about oneself. Also, it is very important that school education takes place in an environment that is aesthetically pleasing. Children should take an active part in creating such an environment for themselves. Individual differences are important as cultural differences. Development and flourishment of skills and capacities would only enhance the individual's life but also enrich the life of community. Education must therefore promote and nourish as wide a range of capacities and skills in our children as possible. ${ }^{3}$

In order to make a child an active member of the society the teacher, must be familiar with the core idea of primary education. The present coursework of D. El. Ed. has all the desirable spaces in its curriculum. The student-teachers who are a part of this study have already gone through the topics on educational perspective during the course. The analysis of data gives us a picture to understand their educational practice.

\section{Choosing Teaching as a Profession:-}

Considering the fact that learning level of children enrolled at elementary level is a great concern for the nation, it seems important to know why people choose teaching as a profession. Our leading question investigates it in detail. According to the responses of student-teachers, a large number of themhave opted for teaching as a profession because they find it interesting. This result contradicts the myth that generally people opt for teaching because they are left with no choice as the percentage of such student-teachers was merely9 percent. Therefore, we can say that the time is changing and people aspire to become teachers. A large number of student-teachers (18.1\%) also opted this profession in order to bring change in the society through their profession. They want to shape the young minds so that they can prepare their students as the active membersofthe society which will contribute in making this society a better place for everyone. 20.4 percent student-teachers have also chosen teaching because they like

\footnotetext{
${ }^{2}$ Position Paper by National Focus Group on Aims of Education, Page 3.

${ }^{3}$ Position Paper by National Focus Group on Aims of Education, Page 5
} 
dealing with kids. The inference from the data reveals the need to reflect upon the issues concerning learning levels whether their existence is due to inadequate interest of teachers in teaching- learning or the problem lies within the education system.

\begin{tabular}{|l|l|l|l|}
\hline Responses of Student-teachers & $\begin{array}{l}\text { First } \\
\text { Preference }\end{array}$ & $\begin{array}{l}\text { Second } \\
\text { Preference }\end{array}$ & $\begin{array}{l}\text { Third } \\
\text { Preference }\end{array}$ \\
\hline Teaching is an interesting profession & $22.7 \%$ & $11.3 \%$ & $13.6 \%$ \\
\hline To share knowledge with children & $13.6 \%$ & $9 \%$ & $11.3 \%$ \\
\hline Lack of options & $9 \%$ & $2.2 \%$ & $4.5 \%$ \\
\hline To enrich self-knowledge & $11 \%$ & $6.8 \%$ & $2.2 \%$ \\
\hline Due to influence of the family & $0 \%$ & $6.8 \%$ & $2.2 \%$ \\
\hline $\begin{array}{l}\text { To pursue higher studies because the timings I teaching } \\
\text { are fixed }\end{array}$ & $4.5 \%$ & $11.3 \%$ & $6.8 \%$ \\
\hline To bring change in the society & $18.1 \%$ & $15.9 \%$ & $11.3 \%$ \\
\hline Like dealing with kids & $20.4 \%$ & $13.6 \%$ & $45.4 \%$ \\
\hline
\end{tabular}

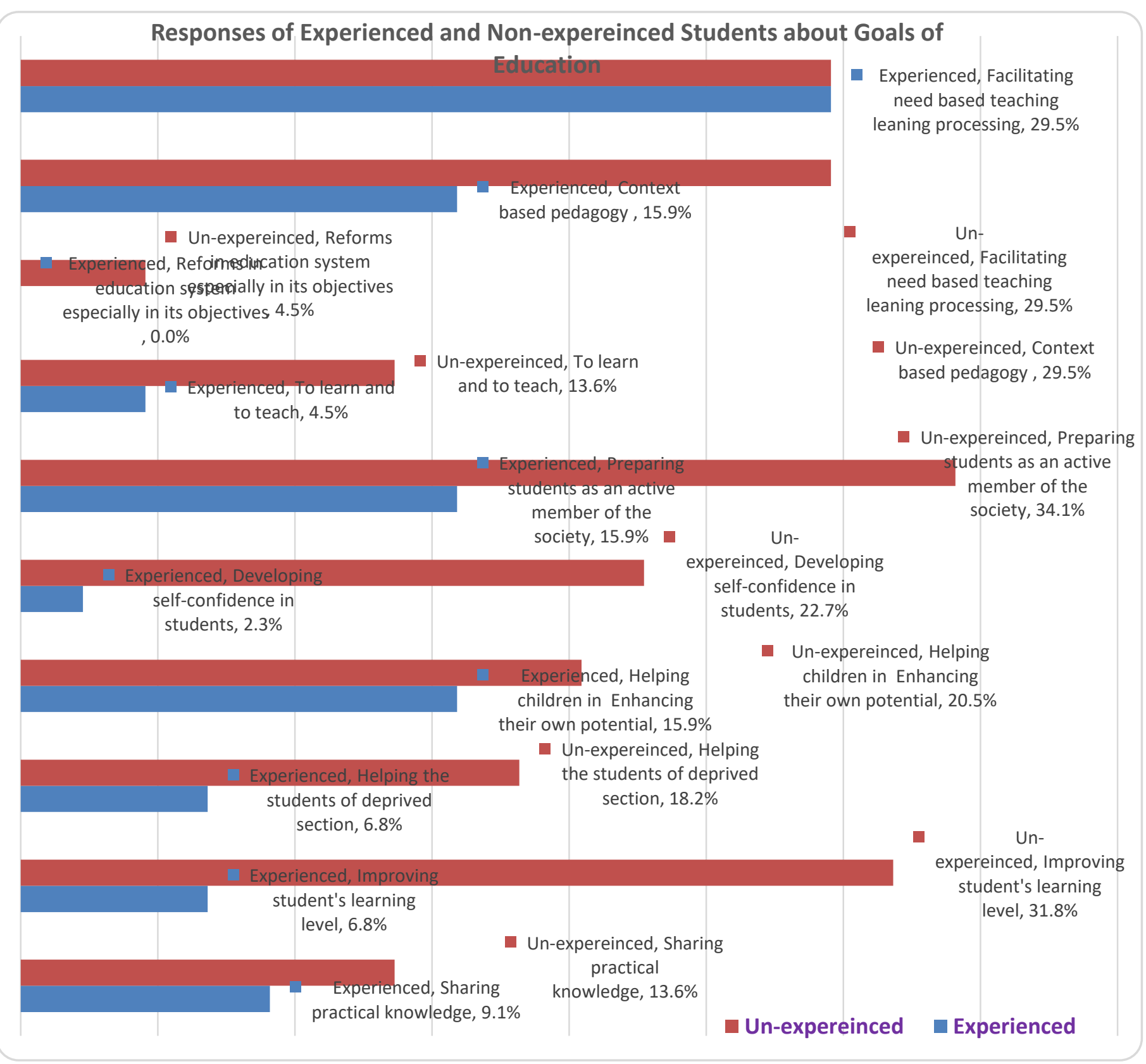




\section{Understanding of Student-Teachers about the Aims of Education:-}

In overall sample, there were 2 categories of student-teachers that are experienced and non-experienced studentteachers. Experienced student-teachers have a teaching experience in the range of 2 months to 16 years whereas non-experienced student-teachers either have no experience or have teaching experience of 1 month. If we look at the data we can observe that there is very less discrepancy between the responses of experienced and nonexperienced student teachers which clearly indicates that the level of understanding of both experienced and nonexperienced respondents is almost similar. There can be number of reasons behind this fact; one of them can be efficiency of pre-service teacher training. Present day pre-service training has filled the gap that experience might have created. Pre-service training has covered almost all the dimensions of teaching. Also, some respondents have misunderstood teaching process with the aim of education. Teaching processes are used in order to fulfil the aims of education. But here, context based pedagogy which is a teaching process is the aims of education for some respondents which clearly signifies the lack in basic understanding about the aims of education. The responses also prove that they are aware about the needs of the student and want to focus on the development of capacities and potential of the students. Also, the respondents are aware about the needs of the society, they want to make their student positively active in society and have not ignored even the deprived section which exists on the periphery.

According to the responses, some major aims of education are facilitating need based teaching learning processing, context based pedagogy, preparing student as an active member of the society and improving students leaning level. If we look at the data carefully we can observe that there is very less discrepancy between the responses of experienced and non-experienced respondents which clearly indicates that the level of understanding of both experienced and non-experienced respondents is almost similar. There can be number of reasons behind this fact, one of them can be efficiency of pre-service training. Present day pre-service training has filled the gap that experience has created. Pre-service training has covered almost all the dimensions of teaching. Also, some respondents have confused teaching process with the aim of education. Teaching processes are used in order to fulfil the aims and objectives of education. But here, context based pedagogy which is a teaching process is the aims of education for some respondents which clearly signifies the lack in basic understanding about the aims of education. The responses also prove that they are aware about the needs of the student and want to focus on the development of capacities and potential of the students. Also, the respondents are aware about the needs of the society, they want to make their student positively active in society and have not ignored even the deprived section which exists on the periphery.

The changes at school level that student-teacher emphasized upon:-

\begin{tabular}{|c|c|c|c|}
\hline Responses of Student Teachers & $\begin{array}{l}\text { Experienced } \\
(\mathrm{N}=13)(\% \text { age })\end{array}$ & $\begin{array}{l}\text { Non-Exp. } \\
\text { N=31 } \\
\text { (\%age) }\end{array}$ & $\begin{array}{l}\text { Total } \\
\mathrm{N}=44 \\
\text { (\%age) }\end{array}$ \\
\hline Fearful Environment & $85 \%$ & $74 \%$ & $74 \%$ \\
\hline Community involvement & $15 \%$ & $19 \%$ & $18 \%$ \\
\hline Resource gap in public \& private schools & $54 \%$ & $48 \%$ & $50 \%$ \\
\hline Dependency on textbooks & $15 \%$ & $22 \%$ & $20 \%$ \\
\hline Inadequate resources & $31 \%$ & $48 \%$ & $43 \%$ \\
\hline Dependency on Officials & $15 \%$ & $23 \%$ & $20 \%$ \\
\hline Dependency on officials & $0 \%$ & $16 \%$ & $11 \%$ \\
\hline Quality of textbooks & $31 \%$ & $7 \%$ & $14 \%$ \\
\hline Non-academic work & $8 \%$ & $7 \%$ & $7 \%$ \\
\hline Retention of Children & $23 \%$ & $36 \%$ & $32 \%$ \\
\hline Poor learning level in English & $15 \%$ & $16 \%$ & $16 \%$ \\
\hline Others & $31 \%$ & $6 \%$ & $14 \%$ \\
\hline
\end{tabular}

School is an institution which is the basic foundation of Education system. But even this foundation has some loop holes and some changes are required for effective functioning of schools. According to student-teachers there are number of changes that should be made but a majority of student-teachers (74\%) prefers to change the fearful environment which haunts the students. Corporal punishments and rigid rules create fear in the minds of the students which hampers their overall growth and development. Both experienced and inexperienced student-teachers want to change the fearful environment which clearly indicates that they have a rare quality of empathizing with the students irrespective of experience. Many respondents (54\%) also want to change the gap between public and private schools in terms of availability of resources. Some student-teachers (20\%) also highlighted their concerns for 
changes in the quality of textbooks. The reason in this difference in opinion can be the in depth knowledge about their subject and books. Retention of children was also one of the issues that the student-teachers (32\%) want to change. The student-teachers also suggested some other issues like poor learning level of children, non-academic engagement of teachers, detention of children etc. which they want to change as a teacher.

\begin{tabular}{|l|l|}
\hline Student-teachers views on when children learn better \\
\hline Responses of Student-teachers & Responses \\
\hline If teaching learning processes are child-centric & $64 \%$ \\
\hline If children get support from family & $16 \%$ \\
\hline If children are themselves interested in learning & $34 \%$ \\
\hline Children learn better in groups & $20 \%$ \\
\hline If children get adequate support from teachers & $18 \%$ \\
\hline Children learn better from their environment & $15 \%$ \\
\hline If teaching is project based & $4 \%$ \\
\hline If teachers use local language and address students' problems & $20 \%$ \\
\hline
\end{tabular}

Perception of Student-teachers about Essential Elements of Learning:-

Every child has its own pace of learning but learning can be made better using number of techniques. According to the results of the study, $63.6 \%$ respondents believe that children learn better in child-centric education. Child-centric education enables full focus on child rather than other variables, which helps child to learn better. Also, children learn better when they are themselves interested in learning, if learning is forced, children do not learn (34.1\%). Adequate support from teachers is also important (18.2\%). It is important for a teacher to understand the child because due to individual differences every child has different needs and different problems. So learning can be made better if a student gets adequate support from the teachers. Language also plays a very important role in learning (20.5\%). Learning is effective and faster if the child is familiar with the language of teaching. Very few respondents think that learning can be made better if it is project-based $(4.5 \%)$.

\section{Student Teacher Perceptions about Importance of Feedback:-}

\begin{tabular}{|l|l|l|l|}
\hline Responses of the Student-Teachers & Experienced & Non-experienced & Total \\
\hline Agree & $92 \%$ & $97 \%$ & $95 \%$ \\
\hline Disagree & $8 \%$ & $3 \%$ & $5 \%$ \\
\hline
\end{tabular}

Feedback is an essential part of learning process. Feedback makes learning more effective because it helps in identification of problems and also neutralizes the problems. According to the results, majority of the studentteachers $(95 \%)$, irrespective of their experience agree with the notion that feedback should be given to the students. The feedback can be given by assigning responsibilities, it can be positive in nature because it acts as an agent of motivation and it helps in enhancing the potential of the students by identifying their weakness. Very few studentteachers (5\%) disagree with this notion because they think that feedback creates fear and insecurity in the mind of the students.

\section{Learning platform for children:-}

School is an institution with a well laid structure which facilitates learning in an organized and systematic manner. Children go to school where teachers facilitate teaching-learning process in a manner that enable every child to coconstruct knowledge which is helpful for these children to achieve their potential. To capture the responses of student-teachers about learning platforms, they were asked whether the children learn only in the school or there are some other platforms also. The responses of all student-teachers except a single case are encouraging as the data of the study reveals that children can learn from other sources. These other sources include family, friends, society, community, Information communication technology, exposure/excursion visits, environment, experiments etc. Only one respondent thinks that school is the only source of learning because it is a disciplined institution. Here, it is important to mention that this response belongs to a person who has just completed her graduation and does not have any experience in education as well as any teacher training. 


\section{Some Beliefs of Student-Teachers about Children:-} Individual Difference:-

\begin{tabular}{|l|l|l|l|}
\hline Responses & Experienced & Non-Experienced & Total \\
\hline Strongly Agree & $69.2 \%$ & $61.3 \%$ & $63.6 \%$ \\
\hline Partial Agree & $23.1 \%$ & $32.3 \%$ & $29.5 \%$ \\
\hline Disagree & $7.7 \%$ & $6.5 \%$ & $6.8 \%$ \\
\hline
\end{tabular}

Individual difference is a fundamental principle of our lives. Every individual differs from one another in different ways. According to the results of the study, maximum student-teachers $(63.6 \%)$ irrespective of their experience agree that some children are more intelligent than other because they are gifted, they get favourable environment at home and they are also blessed some traits that are transferred to them from their parents. Contrary to this 29.5 percent student-teachers think that there is no such difference in children, every child is born similar but the nature of talent differs due to difference in their interest. Everyone is talented except for special children. There is a very minor discrepancy between the opinion of experienced and non-experienced student-teachers which proves that their belief regarding individual differences is almost the same.

\section{Ranking of Students:-}

\begin{tabular}{|l|l|l|l|}
\hline $\begin{array}{l}\text { Responses of Student- } \\
\text { Teachers }\end{array}$ & Experienced & Non-Exp. & Total \\
\hline Agree & $6(46 \%)$ & $16(52 \%)$ & $22(50 \%)$ \\
\hline Disagree & $7(54 \%)$ & $15(48 \%)$ & $22(50 \%)$ \\
\hline
\end{tabular}

Ranking and comparing students has always been an issue of debate. Even this study has not been able to find a clear answer to this question because according to the results the responses of the student-teachers are mixed. 50 percent of student-teachers agree that students should be ranked whereas 50 percent of the student-teachers disagree that students should not be ranked. There is no major discrepancy in the responses of the experienced and inexperienced respondents. Almost half of the respondents agree with the statement because it infuses positivity and motivates the students, acts as a feedback for other students, develops the feeling of healthy competition, helps in making teaching-learning processes effective etc. On the other hand half of the student-teachers disagree with statement because it creates fear and insecurity in the mind of the students which may demotivates them.

\section{Comparing Boys and Girls:-}

According to the previous researches there is no difference in the learning capacity of boys and girls. The results of this study also support this point because 41 percent student-teachers disagree that girls are better in some subjects than boys. According to them it is because there is no relation between genders and learning and interest of the child is primary.

Beside this there are 23 percent student-teachers think that girls are better in some subjects like dance, drawing, creative subjects, languages, memorizing etc. because they are more intelligent and disciplined whereas 36 percent student-teachers partially agree with this statement because they think that girls are better in some subjects like

\begin{tabular}{|l|l|l|l|}
\hline Responses of Student-Teachers & Experienced & Non-Exp. & Total \\
\hline Strongly Agree & $23 \%$ & $23 \%$ & $23 \%$ \\
\hline Partially Agree & $38 \%$ & $35 \%$ & $36 \%$ \\
\hline Disagree & $38 \%$ & $42 \%$ & $41 \%$ \\
\hline
\end{tabular}

music, home science, arts, cooking etc. because they concentrate more, they are more sincere than boys but even after this their performance is similar.

\begin{tabular}{|l|l|l|l|}
\hline Responses of Student-Teacher & Experienced & Non-Exp. & Total \\
\hline Strongly Agree & $8 \%$ & $10 \%$ & $9 \%$ \\
\hline Partially agree & $33 \%$ & $29 \%$ & $30 \%$ \\
\hline Disagree & $59 \%$ & $61 \%$ & $61 \%$ \\
\hline
\end{tabular}

As mentioned above, previous researches state that there is no difference between the learning capacity of both boys and girls. But according to the results of the study 61 percent student-teachers disagree that boys are better in some subjects than girls because according to them children of both the gender are equal, interest is play key role in performance of a child, there is no connection between gender and learning, performance depends upon practice, 
and everyone can learn irrespective of their gender if enough opportunities are provided to them. But, 9 percent student-teachers strongly agree that boys perform better in some subjects than girls because even today, girls do not get enough educational opportunities like boys.

Beliefs about Existence of innate abilities in some children:-

\begin{tabular}{|l|l|l|l|}
\hline Reponses of Student-Teachers & Experienced & Non-Exp. & Total \\
\hline Strongly Agree & $8 \%$ & $29 \%$ & $23 \%$ \\
\hline Partially Agree & $38 \%$ & $13 \%$ & $20 \%$ \\
\hline Disagree & $54 \%$ & $58 \%$ & $57 \%$ \\
\hline
\end{tabular}

The analysis of data reveals that 23 percent student-teachers strongly agree with the statement as according to them innate traits and qualities do affect the learning potential of the student. Opposite to this 57 percent student-teachers disagree that there are no subjects that only some can learn. According to them there is no such in born factor that affects learning some specific subjects because by birth every child is same, knowledge can be acquired by practice, learning depends upon individual differences and not on gender, children learn by practice not by any inborn quality. The context where a child passes most of the time and learning processes significantly impact the learning of children.

Teacher as single source of learning for children:-

Teacher is an integral part of student's life. Teacher plays an important role in making the student proficient. But there are number of other sources which can be helpful in learning. According to the results of our study, majority of

\begin{tabular}{|l|l|l|l|}
\hline Responses of Student-Teachers & Experienced & Non-Experienced & Total \\
\hline Agree & Nil & $26 \%$ & $18 \%$ \\
\hline Disagree & $92 \%$ & $71 \%$ & $77 \%$ \\
\hline Non-Relevant & $8 \%$ & $3 \%$ & $5 \%$ \\
\hline
\end{tabular}

the student-teachers $(77 \%)$ disagree with the statement that learning can be facilitated only by teachers, according to them there are number of other sources where a child can learn. The sources include experiences, environment, family, Information communication technology, self-study, society, friends, parents, environment and neighborhood.

\begin{tabular}{|l|l|l|l|}
\hline Responses on Student Teachers on their preference & First Choice & First Choice & Third Choice \\
\hline Use of ICT & $47.7 \%$ & $18.2 \%$ & $9.1 \%$ \\
\hline Teaching Learning Material & $18.2 \%$ & $34.1 \%$ & $18.2 \%$ \\
\hline Books/Magazines/Library & $6.8 \%$ & $11.4 \%$ & $22.7 \%$ \\
\hline Mutual exchange of Experiences & $11.4 \%$ & $11.4 \%$ & $22.7 \%$ \\
\hline Local Context & $13.6 \%$ & $9.1 \%$ & $11.4 \%$ \\
\hline Others & $2.3 \%$ & $16 \%$ & $16 \%$ \\
\hline
\end{tabular}

This implies that teacher acts as a guide and a motivator in the life of a student. They give direction to the life of a child using above mentioned means. They are the ones who direct the life of a child in an appropriate direction.

\begin{tabular}{|l|l|l|l|}
\hline Responses of Student-Teachers & Experienced & Non-Exp. & Total \\
\hline Strongly Agree & $61.50 \%$ & $74 \%$ & $70 \%$ \\
\hline Partially agree & $15 \%$ & $23 \%$ & $20 \%$ \\
\hline Disagree & $23.50 \%$ & $3 \%$ & $10 \%$ \\
\hline
\end{tabular}

Children from Illiterate families cannot learn easily:-

India has been struggling to curb Illiteracy since Independence and have also got remarkable results. Today India's literacy rate is at 74.04 percent. Even after consistent efforts by government, there are number of Illiterate families in India. Right from the launching of District Primary Education Program and SarvaShikhaAbhyaan, the children of these illiterate families have also started going go to school. The analysis indicated that, 24 percent experienced student-teachers think that children who come from illiterate families do not face difficulties in learning whereas only 3 percent non-experienced ones thinks the same. There is a difference in the opinion of respondents of both the categories because the experienced ones have a better insight of children's learning patterns and learning capacities. But, majority (70\%) of the respondents agree that children who come from illiterate families face difficulties in learning. According to them unavailability of educational environment affects the level of learning. The parents of uneducated families are unaware about the importance of education which develops a carefree attitude towards education. They do not get proper guidance at home and face a lot of hurdles in their academic journey. 
Resource Support:-

\begin{tabular}{|l|l|l|l|}
\hline Choice of Student Teachers for Receiving Resource Support \\
\hline Responses of Student-teachers & First Choice & Second Choice & Third Choice \\
\hline Colleagues & $45.5 \%$ & $9.1 \%$ & $13.6 \%$ \\
\hline Senior Teacher & $9.1 \%$ & $31.8 \%$ & $9.1 \%$ \\
\hline Friends & $4.5 \%$ & $2.3 \%$ & $11.4 \%$ \\
\hline Organizations/Institutions & $2.3 \%$ & $15.9 \%$ & $11.4 \%$ \\
\hline Community/Society & $13.6 \%$ & $18.2 \%$ & $22.7 \%$ \\
\hline Principal & Nil & $9.1 \%$ & $9.1 \%$ \\
\hline Self & $9(20.5 \%)$ & $1(2.3 \%)$ & $6(13.6 \%$ \\
\hline Others & $2(4.5 \%)$ & $5(11 \%)$ & $4(10 \%)$ \\
\hline
\end{tabular}

Resource support is very important in order to make teaching learning processes more appropriate and impactful in regard to learning of children. While probed the question about the resources they will prefer to access for their own learning enhancement. 45 percent of the student-teachers stated that they will contact their colleagues for better teaching-learning. Respondents spend a lot of time with their Colleagues and colleagues can share knowledge and other resource material in their areas of expertise. A lot of student-teachers (9.1\%) also think that they can also take such help from their senior teachers because they are more experienced and they have more expertise. Other sources include Principal, Family, Self, Society/Community, Institutions, friends etc.

\begin{tabular}{|l|l|}
\hline Sources & Responses \\
\hline Friends & $27.27 \%$ \\
\hline Family & $6.81 \%$ \\
\hline School & $13.63 \%$ \\
\hline Books & $20.54 \%$ \\
\hline Everywhere & $15.90 \%$ \\
\hline Society & $4.54 \%$ \\
\hline Others & $9 \%$ \\
\hline
\end{tabular}

Resource material helps teacher in improving the quality of teaching-learning processes. According to the results of our study there are number of sources from where resource material can be acquired. Almost half of student-teachers think that resource material can be acquired using Information communication technology. Many respondents also think that teaching learning material, local context, books and mutual exchange of experiences can be of great help. But other respondents think that educational visits, CBO's and support from concerned institution is least helpful.

Knowledge plays a vital role in socialization process of an individual. It not only strengthens the academic base of the individual but also makes practitioner more reflective, practice-oriented and facilitate outcome based practices. There are number of sources for acquisition of knowledge. According to the results of the study, $27 \%$ respondents believe that they can acquire knowledge from friends. A mere casual interaction with friends can be helpful for the respondents and friends prove to be a crucial source of knowledge. According to $21 \%$, books are also a major source of knowledge because they give in depth knowledge about a particular subject which helps in developing a better insight. Other sources include Information communication technology, society, students, nearby environment, newspapers, schools etc.

\section{Key Inferences from the Study:-}

The role of a teacher is very crucial in a society. A teacher inspires and encourages the students to achieve desired goals in life. The performance of the students partially depends upon the excellence and competence of a teacher. And in order to make a teacher competent enough, the government of India have introduced pre-service trainings. Pre-service trainings consist of studies of theory and practice of teaching, where practice teaching is a very crucial ingredient of the teaching. In general, the course has elements of psychology, educational philosophy and sociology of education and instruction about teaching of certain subjects. Also included are principles such as aims of education, curriculum, nature and characteristics of child development, method of teaching and learning and introduction to resources that a teacher must draw on. ${ }^{4}$

\footnotetext{
${ }^{4}$ Conceptualization and Implementation of Pre-service Education Curriculum (BTC) 2010-12, Uttarakhand ,Page6
} 
Teaching is considered as a noble profession. In spite of moral prestige that is attached to it, it is a common belief that people choose teaching as a profession because of unemployment or because they are left with no choice, the result of the study challenged this myth as a significant number of students chose teaching as a profession because of interest. They aspire to become teachers. This implies that the time is changing and the belief that it is forced, no longer exists. But our education system is still facing a number of problems. Now the question that arises here is, whether the problem is with teachers or there is a problem with our education system. As per the responses of our study, student-teachers are opting for teaching voluntarily, so the possibility of the problem being attached with teacher reduces.

The results of the study also threw light on the fact that there was no gap in understanding of between experienced and non-experienced respondents as student-teachers. This implies that either there is deterioration in the richness of experience or the transactional value of D. El. Ed curriculum is very high.

We are aware about the fact that our education system has some loop holes and there is a need for some significant changes. According to the analysis of the data, it can be concluded that student-teachers are well aware about the ground realities of education system. They are aware about the problems faced by students as well as teachers. This implies that they empathize well with the students as even after facing number of problems that exist in our education system these student-teachers want to work for betterment and growth which is trait of an ideal teacher. In spite of being attached with such a reputed occupation and being a teacher, majority of the student-teachers think that teacher, schools or textbooks are not the only sources of knowledge, and children can learn from many other sources also like friends, family, society, community, neighborhood, Information Communication Technology etc. It implies that they are well aware of the advanced understanding of effective pedagogy and appropriate learning appropriate platforms for children.

Student-teachers are also aware about social realities and think about the welfare of the society. This can also be concluded because they want to make their students as the functioning members of the society and also want to help the students coming from marginalized section of the society. They also understand the plight of students who come from relatively uneducated or unschooled families and are ready to give in extra efforts in order to shape their future.

Beliefs of student-teachers play vital role in shaping the minds of the students. Sometimes some beliefs even get transferred from teacher to the students during the process of teaching. But, these student teachers are going through the pre-service training and as a result think rationally. They do not hold any irrational belief. They believe that girls and boys are equal partners and should not be considered contrary to each other. They do not favor or support any gender which can facilitate quality discussions in the classroom. They also do not believe in age limit of learning, according to them learning is a life-long process as learning does not have any end and can be started from any age. It can also be concluded that these student-teachers are well equipped with technology. They do not believe in only sticking to books, most of the student-teachers rely on Information communication technology for as a source of knowledge or resource support. They know the importance of Information communication technology and are equipped with modern technology in order to educate the modern generation. *** 